\title{
DAMPAK KEBIJAKAN PRIVATISASI TERHADAP PEREKONOMIAN DI INDONESIA
}

\author{
Rizka Ardiani1), Saiful1), Karisma1), Sophi Alifiyah1), Devi Rachmawati1) \\ 1) Program Studi Ilmu Administrasi Publik, Ilmu Pemerintahan, Ilmu Politik \\ Universitas 17 Agustus 1945 Jakarta
}

\begin{abstract}
Abstrak
Kebijakan privatisasi menjadi tren global yang terjadi baik di negara maju maupun negara berkembang. Privatisasi atau penjualan aset negara dipandang sebagai program ekonomi yang diperlukan untuk menghindari penghematan yang tinggi dengan membebaskan BUMN dari kerugian. Program privatisasi dapat meningkatkan efisiensi dan mendorong pertumbuhan ekonomi, terutama di bidang infrastruktur, pendidikan, dan kesehatan. Privatisasi adalah kebijakan yang dilaksanakan oleh pemerintah yang mengalihkan sebagian atau seluruh aset yang dimiliki oleh negara kepada pihak swasta. Privatisasi BUMN telah menimbulkan banyak kontroversi di kalangan masyarakat Indonesia. Selama privatisasi dapat membawa manfaat yang lebih baik, beberapa akan baik-baik saja dengan privatisasi, sementara yang lain akan dianggap nonnasionalis dan menolak privatisasi untuk mengkonsumsi aset negara. Tujuan yang dicapai melalui kebijakan privatisasi adalah untuk memberikan kontribusi keuangan kepada organisasi negara dan komersial, akses terbuka ke pasar internasional, dan transfer teknologi ke organisasi komersial. Di Indonesia, privatisasi dianggap penting karena mempromosikan tata kelola perusahaan yang baik. Privatisasi didasarkan pada prinsip transparansi, independensi, tanggung jawab, akuntabilitas, kewajaran dan harga terbaik, dengan memperhatikan kondisi pasar. Dengan demikian, pertumbuhan ekonomi Indonesia akan meningkat.
\end{abstract}

Kata Kunci: Privatisasi, Perekonomian Indonesia

\begin{abstract}
The privatization policy has become a global trend that occurs in both developed and developing countries. Privatization or sale of state assets is seen as an economic program needed to avoid high savings by freeing BUMN from losses. The privatization program can increase efficiency and encourage economic growth, especially in the fields of infrastructure, education, and health. Privatization is a policy implemented by the government that transfers part or all of the assets owned by the state to the private sector. The privatization of BUMN has caused a lot of controversy among the Indonesian people. As long as privatization can bring better benefits, some will be fine with privatization, while others will be considered non-nationalists and reject privatization to consume state assets. The objectives achieved through the privatization policy are to provide financial contributions to state and commercial organizations, open access to international markets, and transfer of technology to commercial organizations. In Indonesia, privatization is considered important because it promotes good corporate governance. Privatization is based on the principles of transparency, independence, responsibility, accountability, fairness and the best price, taking into account market conditions. Thus, Indonesia's economic growth will increase.
\end{abstract}


Keywords: Privatization, Indonesian Economy

\section{PENDAHULUAN}

Privatisasi merupakan salah satu kebijakan yang ditempuh oleh Pemerintah Indonesia untuk mengalihkan sebagian atau seluruh aset milik negara kepada swasta. Pengalihan aset dapat dipahami sebagai pengalihan hak administratif dari pemerintah kepada swasta. Selain itu, menurut Boardman (1989), perubahan kepemilikan ini mempengaruhi kinerja perusahaan dengan meningkatkan pemanfaatan sumber daya. Program dan kebijakan privatisasi dilaksanakan secara terpisah dari ekonomi politik nasional. Seperti yang diungkapkan Bank Dunia (2002), keberhasilan proses privatisasi tidak lepas dari aspek politik dan ekonomi. Keterlibatan legislator dan persiapan manajemen perusahaan terafiliasi sangat mempengaruhi keberhasilan proses privatisasi. Untuk menyambut datangnya era global dan pasar bebas, pemerintah harus menciptakan daya saing perusahaan swasta dan publik untuk meningkatkan keterampilan mereka. Hasil survei menunjukkan bahwa privatisasi dapat meningkatkan kinerja perusahaan. Stiglitz (1988) dan Bos (1991) berpendapat bahwa privatisasi dapat meningkatkan kinerja karena dapat mengubah insentif untuk tata kelola dan manajemen perusahaan menjadi yang terbaik. Namun pada kenyataannya, kebijakan privatisasi Indonesia bukanlah jalan utama untuk mereformasi BUMN. Privatisasi itu akan menjadi keputusan yang tepat jika didukung oleh kondisi tertentu. Yang utama adalah adanya infrastruktur ekonomi dan hukum yang memadai dan kapasitas pemerintah untuk melakukan privatisasi. Prosedurnya tepat dan transparan.

Privatisasi BUMN telah menimbulkan kontroversi di kalangan penduduk Indonesia. Selama privatisasi adalah untuk tujuan yang terbaik, beberapa akan menerima privatisasi, sementara yang lain akan dilihat sebagai non-nasionalis dan menolak privatisasi. Sebuah studi internasional yang dilakukan oleh Perserikatan Bangsa-Bangsa menyimpulkan bahwa privatisasi yang sukses hanya ada di negaranegara di mana pemerintah telah menunjukkan kemampuan mereka untuk mengendalikan perusahaan milik negara. Privatisasi kemungkinan akan gagal untuk negara-negara di mana pemerintah tidak dapat secara efektif dan efisien mengelola perusahaan milik negara. Dengan demikian, Pemerintah Indonesia belum menunjukkan kemampuannya mengelola BUMN secara optimal dan berdasarkan pengalaman empiris, proses privatisasi lebih banyak menimbulkan masalah daripada keuntungan (Basri, 2009). 
Privatisasi perusahaan publik didasarkan pada pendekatan teori hak milik (The Property Right Approach). Pada pendekatan ini dibahas mengenai perbedaan antara perusahaan publik dan swasta. Struktur ekonomi yang dikendalikan oleh negara berbeda dari struktur ekonomi yang dikendalikan oleh sektor swasta dalam hal fungsi maksimalisasi. Dalam struktur ekonomi yang dikendalikan negara, organisasi negara dipengaruhi dan dikendalikan oleh sekelompok politisi, menteri, dan pemimpin publik. Terutama dalam ekonomi swasta, pemilik bisnis swasta (pemegang saham) memaksimalkan nilai organisasi dengan memastikan bahwa manajer mengalokasikan sumber daya maksimum. Kemampuan dan kemauan pemilik untuk mentransfer kepemilikan mengarah pada realokasi sumber daya dari utilitas rendah ke tinggi. Jensen dan Meckling (1976) dan Boycko dkk. Penulis hak milik tersebut, menunjukkan bahwa struktur kepemilikan yang lebih besar dalam perekonomian mengarah pada potensi alokasi sumber daya yang lebih besar, yang sangat tergantung pada sejauh mana perekonomian diurus. Kepemilikan tunggal adalah perusahaan yang dimiliki oleh seorang individu yang bebas untuk memiliki, menggunakan, dan menukar hak milik pribadi dalam suatu aset dalam suatu batas hukum. Hak-hak ini memberikan kepada pemilik individu aset perusahaan swasta. Menggunakan barang-barang ini untuk menghasilkan barang dan jasa yang diminta oleh konsumen dengan biaya di bawah harga pasar meningkatkan dan meningkatkan kebahagiaan. Sebaliknya, ketika biaya produksi melebihi harga pasar, terjadi kerugian yang menurunkan nilai perusahaan serta kesejahteraan dan pendapatan pemilik aset sosial. Pada pemilik sektor atau pihak swasta mendapatkan keuntungan dari manajemen yang efisien dan menderita salah urus.

Teori privatisasi lainnya adalah teori yang memberikan analisis yang lebih luas daripada pendekatan pilihan publik, pendekatan hak milik. Pendekatan pilihan publik mengasumsikan bahwa politisi, pejabat, dan pemilik perusahaan milik negara lebih mementingkan urusannya sendiri untuk memaksimalkan urusannya. Pendekatan ini berasumsi bahwa politisi mengutamakan kepentingannya dalam mencapai cita-cita atau cita-cita pribadinya, dengan batasan tidak akan kehilangan posisinya di pemilu setelahnya. Bagi politisi, mempertahankan kekuasaan adalah tujuan utama mereka, sehingga politisi menggunakan layanan publik untuk keuntungan pribadi. Ternyata politisi tidak memiliki insentif untuk secara efektif mengelola penggunaan sumber daya nasional dan efisiensi perusahaan publik. Layanan publik menawarkan politisi kesempatan untuk mengejar kepentingan pribadi mereka sendiri. Artinya pemilihan ulang di pemilu berikutnya dengan menambah lebih banyak pekerja dan menstabilkan daya beli. 


\section{METODE PENELITIAN}

Metode penelitian yang digunakan dalam tinjauan ini adalah metode kualitatif untuk mengidentifikasi dan mengkonseptualisasikan topik penelitian yang telah ditentukan, yaitu dampak kebijakan privatisasi terhadap perekonomian. Diharapkan hasil penelitian kualitatif akan ditemukan melalui berbagai bentuk analisis penelitian deskriptif kualitatif dan analisis isi dan diskusi yang digunakan.

\section{PEMBAHASAN}

\section{Kebijakan Pelaksanaan Privatisasi BUMN di Indonesia}

Privatisasi BUMN Indonesia dimulai pada awal 1980-an sebagai bagian dari sistem pengembangan perusahaan publik yang bertujuan untuk mencapai GCG. Sejak saat itu, istilah BUMN baru dikenal sejak diterbitkannya PP No.3 Tahun 1983 tentang Pembinaan dan Tata Cara Pengelolaan Perusahaan Jasa (Perjan), Perusahaan Umum (Perum) dan Perusahaan Umum (Persero). Privatisasi Badan Usaha Milik Negara di Indonesia sebagai pelaksana undang-undang no. 19 Tahun 2003, khususnya Peraturan Pemerintah No. 33 Tahun 2005 tentang Tata Cara Privatisasi Perusahaan Penanggung Jawab dan Peraturan Pemerintah No. 59 Tahun 2009 tentang Perubahan atas Peraturan Pemerintah No. 33 tahun 2005. Pemerintah tidak dapat bertindak sendiri dalam pelaksanaan program privatisasi. Perusahaan yang dipilih dan memenuhi kriteria tertentu harus berkonsultasi terlebih dahulu dengan DPRRI sesuai dengan ketentuan pasal 82 UU No. 19 Tahun 2003:

1) Privatisasi memerlukan tindakan proaktif untuk memilih perusahaan. Berdasarkan standar yang ditetapkan oleh peraturan pemerintah,

2) Perusahaan yang memenuhi standar yang dipilih dan ditetapkan akan terbuka untuk umum dengan berkonsultasi dengan DPR setelah direkomendasikan oleh Menteri Keuangan.

Hal ini tentu diperlukan untuk meredam resistensi publik secara umum, karena DPR RI mewakili rakyat Indonesia. Kami telah berdiskusi dengan DPR RI dengan harapan proses privatisasi berjalan dengan baik. Ketidakmampuan untuk melakukan privatisasi sekurang-kurangnya harus memenuhi standar industri/industri atau profesi yang berdaya saing tinggi atau sektor/industri teknologi yang berkembang pesat. Sedangkan badan usaha yang tidak dapat disetarakan adalah cabang yang dikelola oleh peraturan perundang-undangan yang hanya dapat dikelola oleh Badan Usaha Milik Negara (BUMN). Bisnis yang bergerak di bidang tertentu di mana pemerintah memiliki tanggung jawab untuk melindungi kepentingan publik dan bisnis sumber daya alam. Persero 
tidak hanya dimungkinkan oleh regulasi di bidang pasar modal, tetapi juga secara umum terlibat dalam bidang persaingan, karena privatisasi harus selalu memperhatikan kepentingan semua. Pemerintah dapat melaksanakan program privatisasi di Indonesia setelah DPRRI mengesahkan RAPBN, yang menetapkan target pendapatan nasional berdasarkan hasil dari proses privatisasi itu sendiri. Rencana privatisasi yang diusulkan dijelaskan dalam Program Privatisasi Tahunan yang pelaksanaannya dibahas dengan DPRRI. Dengan menyampaikan RAPBN kepada DPRRI, pemerintah akan mendaftarkan badan usaha milik negara yang akan diprivatisasi pada tahun anggaran yang bersangkutan guna mencapai target penerimaan negara pasca privatisasi yang telah disusun untuk RAPBN. Oleh karena itu, persetujuan DPRRI atas RAPBN dimaksud termasuk persiapan pemerintah untuk privatisasi BUMN yang dilaksanakan sesuai dengan ketentuan Pasal 2 UU. 2003 tentang Keuangan Negara 17. Rencana privatisasi yang disetujui DPRRI dituangkan dalam program privatisasi tahunan sebagaimana dimaksud dalam Pasal 12 PP No. 33 2005. Privatisasi didasarkan pada prinsip transparansi, transparansi, independensi, akuntabilitas, akuntabilitas, kewajaran dan harga terbaik dengan mempertimbangkan kondisi pasar. Dalam hal ini, kondisi pasar yang tercantum adalah kondisi pasar nasional dan internasional.

Pelaksanaan privatisasi di Indonesia berdasarkan Pasal 78 UndangUndang No.19 tahun 2003 tentang BUMN hanya dimungkinkan dengan tiga macam metode saja, yaitu :

a) Penjualan saham berdasarkan ketentuan pasar modal (Initial Public Offering)

b) Penjualan saham langsung kepada investor (Strategic Sales)

c) Penjualan saham kepada manajemen dan/atau karyawan yang bersangkutan (Employee and/or Management Buy Out)

Setelah dilakukannya privatisasi diharapkan akan terjadi perubahan atas budaya perusahaan sebagai akibat dari masuknya pemegang saham baru, baik melalui penawaran umum maupun melalui penyertaan langsung. Perusahaan akan menghadapi pada kewajiban pemenuhan persyaratan-persyaratan keterbukaan yang merupakan persyaratan utama dari suatu proses penawaran umum, atau adanya sasaransasaran perusahaan yang harus dicapai sebagai akibat masuknya pemegang saham baru. Pada budaya perusahaan yang berubah tersebut akan dapat mendorong peningkatan kinerja perusahaan yang selanjutnya akan dapat mempertinggi daya saing perusahaan dalam berkompetisi dengan pesaing-pesaing, baik nasional, regional, bahkan global sehingga pada akhirnya akan dapat memberikan kontribusi yang lebih besar terhadap perekonomian nasional dalam bentuk barang dan jasa yang 
semakin berkualitas dan terjangkau harganya, serta penerimaan negara dalam bentuk pajak yang akan semakin besar pula.

\section{Dampak Privatisasi Terhadap Perekonomian di Indonesia}

Pada dasarnya privatisasi BUMN dipandang sebagai langkah untuk mengurangi intervensi pemerintah di bidang ekonomi yang seharusnya dilakukan oleh swasta. Privatisasi diharapkan dapat meningkatkan daya saing dan efisiensi dunia usaha yang akan mendukung pertumbuhan ekonomi Indonesia. Namun, privatisasi pemerintah saat ini bukan untuk tujuan ini tetapi untuk menutupi defisit anggaran negara. BUMN adalah "milik negara", tetapi tidak ada cukup fakta bagi pemerintah untuk menjualnya untuk menutup kesenjangan modal operasi. Anggaran Kelemahan Anggaran merupakan tanggung jawab instansi pemerintah dan harus dikoreksi dengan kinerja dan bukan oleh instansi lain. Berbagai manfaat privatisasi adalah:

1) Budaya sektor swasta mulai mempengaruhi bisnis dan perlu lebih efisien. Selain itu, peningkatan keuntungan menyebabkan kenaikan harga saham (jika pemerintah masih memiliki saham, pemerintah juga akan mendapatkan keuntungan dari peningkatan nilai saham).

2) Penjualan saham di pasar modal telah menimbulkan masalah dengan aturan pasar modal, terutama dalam hal transparansi perusahaan.

3)Keterlibatan karyawan telah meningkatkan keterlibatan karyawan dalam pengendalian perusahaan (Gayle, 1990).

Shirley dan Neils (1992) menekankan manfaat privatisasi dalam meningkatkan transparansi, meningkatkan peran mekanisme pengelolaan pasar, dan mengurangi tekanan dan campur tangan politik (Siahaan, 2000). Todaro (1989) menyatakan bahwa privatisasi dapat merangsang inisiatif pemerintah dengan mengurangi pertumbuhan belanja publik, meningkatkan pendapatan tunai untuk membayar utang, di samping meningkatkan efisiensi, produksi dan penghematan biaya. Terakhir adalah perluasan kepemilikan dan partisipasi nasional dalam perekonomian nasional. Berdasarkan temuan perusahaan privatisasi, manfaat program privatisasi kemungkinan disebabkan oleh beberapa faktor, antara lain: (Ii) Peraturan yang tepat dan pantas dari suatu perusahaan tertentu yang mempengaruhi kepentingan umum. (iii) Perubahan kepemilikan badan hukum (Goeltom, 1995).

Beberapa studi menunjukkan bahwa privatisasi memiliki dampak positif terhadap pertumbuhan dan lapangan kerja. Pertumbuhan adalah hasil dari peningkatan efisiensi di tingkat perusahaan. Bukti empiris menunjukkan bahwa pengangguran total cenderung turun, mengingat kekhawatiran tentang meningkatnya pengangguran. Namun, beberapa kelompok pekerja mungkin mengalami hal yang sebaliknya (Davis, 2000). 
Privatisasi juga memaksa perusahaan untuk menerapkan kebijakan yang mengurangi ketimpangan akses barang dan jasa dengan melakukan pembatasan KKN. Dalam jangka panjang, terdapat peluang yang lebih besar untuk berupaya mempromosikan kepemilikan yang lebih luas atas properti dan kondisi kelembagaan yang kondusif bagi pengembangan ekonomi yang kompetitif dan sistem politik yang demokratis. Harus diakui juga bahwa sementara privatisasi meningkatkan pemerataan dalam bentuk penurunan pendapatan dan ketidaksetaraan akses, beberapa privatisasi dilakukan dengan mengorbankan orang miskin. Misalnya, ketika Kereta Api India memotong subsidi, orang miskin paling terpukul. Dampak dari kebijakan privatisasi BUMN terlihat melalui perubahan kebijakan pemerintah dan pengawasan regulasi. Jika dilihat sebagai sarana transisi ke pasar bebas, kegiatan ekonomi lebih kompetitif, dengan jaminan tidak ada hambatan persaingan, baik dalam bentuk undang-undang atau peraturan, aturan, regulasi atau subsidi. Ini akan lebih terbuka untuk sejumlah kekuatan pasar.

Kebijakan privatisasi terkait dengan kebijakan luar negeri yang penting seperti tarif, nilai tukar, dan peraturan bagi investor asing. Ini juga membahas kondisi pasar keuangan, termasuk akses permodalan, penerapan pajak dan peraturan yang tepat, dan kebijakan internal, termasuk kepastian hukum dan bobot sumber daya untuk memprediksi kemungkinan perselisihan komersial. Efek lain yang sering dirasakan oleh kebijakan privatisasi adalah kepemilikan negara diperluas ke sektor swasta, mengurangi konsentrasi kepemilikan pada kelompok atau suatu perusahaan. Sebagai sarana transisi ke pasar bebas, kegiatan ekonomi lebih terbuka terhadap kekuatan yang lebih kompetitif di pasar, memastikan bahwa tidak ada hambatan persaingan dalam bentuk regulasi, regulasi. Untuk melakukan ini, kita perlu mengadopsi kebijakan yang dapat mendukung pertumbuhan dan menarik investasi swasta dengan menghilangkan hambatan masuk pasar dan menghilangkan efek mengganggu pada kerjanya. Program privatisasi harus menekankan manfaat mengubah monopoli publik menjadi milik pribadi. Hanya terbatas pada kepentingan ekonomi dan politik. Dengan pengalihan kepemilikan, alternatifnya adalah menerbitkan saham kepada semua orang dan pegawai BUMN yang terlibat merasa memiliki dan dengan senang hati berpartisipasi untuk meningkatkan kinerjanya. Dengan demikian dapat berpartisipasi dalam manajemen dan memotivasi karyawan. Hal ini dapat berdampak pada produktivitas karyawan dan meningkatkan keuntungan.

\section{KESIMPULAN}

Program privatisasi dapat meningkatkan efisiensi dan mendorong pertumbuhan ekonomi, terutama di bidang infrastruktur, pendidikan, 
dan kesehatan. Privatisasi adalah kebijakan yang dilaksanakan oleh pemerintah yang mengalihkan sebagian atau seluruh aset yang dimiliki oleh negara kepada pihak swasta. Privatisasi BUMN telah menimbulkan banyak kontroversi di kalangan masyarakat Indonesia. Selama privatisasi dapat membawa manfaat yang lebih baik, beberapa akan baik-baik saja dengan privatisasi, sementara yang lain akan dianggap non-nasionalis dan menolak privatisasi untuk mengkonsumsi aset negara. Tujuan yang dicapai melalui kebijakan privatisasi adalah untuk memberikan kontribusi keuangan kepada organisasi negara dan komersial, akses terbuka ke pasar internasional, dan transfer teknologi ke organisasi komersial. Di Indonesia, privatisasi dianggap penting karena mempromosikan tata kelola perusahaan yang baik. Privatisasi didasarkan pada prinsip transparansi, independensi, tanggung jawab, akuntabilitas, kewajaran dan harga terbaik, dengan memperhatikan kondisi pasar (domestik dan internasional). Dengan demikian, pertumbuhan ekonomi Indonesia akan meningkat.

Pada pelaksanaan privatisasi BUMN, Pemerintah dapat melakukan program privatisasi di negara Indonesia setelah DPR-RI memberikan persetujuan atas RAPBN yang di dalamnya terdapat target penerimaan negara dari hasil privatisasi. Rencana privatisasi sebagaimana dimaksud dituangkan dalam program tahunan privatisasi yang pelaksanaannya dikonsultasikan kepada DPR-RI. Pada saat pengusulan RAPBN kepada DPR-RI, pemerintah menyertakan daftar BUMN yang akan di privatisasi dalam tahun anggaran yang bersangkutan untuk memenuhi target penerimaan negara dari hasil privatisasi yang direncanakan dalam RAPBN tersebut. Privatisasi dilakukan berdasarkan prinsip-prinsip transparansi, kemandirian akuntabilitas, pertanggungjawaban, kewajaran, dan prinsip harga terbaik dengan memperhatikan kondisi pasar.

Beberapa studi menunjukkan bahwa privatisasi memiliki dampak positif terhadap pertumbuhan dan lapangan kerja. Pertumbuhan adalah hasil dari peningkatan efisiensi di tingkat perusahaan. Bukti empiris menunjukkan bahwa pengangguran total cenderung turun, mengingat kekhawatiran tentang meningkatnya pengangguran. Namun, beberapa kelompok pekerja mungkin mengalami hal yang sebaliknya (Davis, 2000). Harus diakui juga bahwa sementara privatisasi meningkatkan pemerataan dalam bentuk penurunan pendapatan dan ketidaksetaraan akses, beberapa privatisasi dilakukan dengan mengorbankan orang kurang mampu. Efek lain yang sering dirasakan oleh kebijakan privatisasi adalah kepemilikan negara diperluas ke sektor swasta, mengurangi konsentrasi kepemilikan pada kelompok atau suatu perusahaan. Sebagai sarana transisi ke pasar bebas, kegiatan ekonomi 
lebih terbuka terhadap kekuatan yang lebih kompetitif di pasar, memastikan bahwa tidak ada hambatan persaingan dalam bentuk regulasi, regulasi atau subsidi. Untuk melakukan ini, kita perlu mengadopsi kebijakan yang dapat mendukung pertumbuhan dan menarik investasi swasta dengan menghilangkan hambatan masuk pasar dan menghilangkan efek mengganggu pada usahanya. Program privatisasi harus menekankan manfaat mengubah monopoli publik menjadi milik pribadi. Hanya terbatas pada kepentingan ekonomi dan politik. Dengan pengalihan kepemilikan, alternatifnya adalah menerbitkan saham kepada semua orang dan pegawai BUMN yang terlibat merasa memiliki dan dengan senang hati berpartisipasi untuk meningkatkan kerja. Dengan demikian dapat berpartisipasi dalam manajemen dan memotivasi karyawan. Hal ini dapat berdampak pada produktivitas karyawan dan meningkatkan keuntungan.

\section{DAFTAR PUSTAKA}

Siahaan, F. A., \& Hartono, S. R. "Privatisasi Badan Usaha Milik Negara " Jurnal Undip, 9374 (undip.ac.id)

Aprilina, V. "Dampak Privatisasi Pada Kinerja Keuangan Badan Usaha Milik Negara (BUMN) Di Indonesia” JRAK, Vol. 4, No. 1, Hal. 1-12.

Maro'ah, S. "Kebijakan Privatisasi dan Pengaruhnya Dalam Perekonomian Makro di Indonesia" BALANCE Economics, Bussiness, Management and Accounting

Journal Thn. V, No. 9/ Juli /2008 Published by Faculty of Economic Muhammadiyah Surabaya ISSN : 1693-9352.

Dampak_Privatisasi_di_Indonesia_Studi_Ka.pdf

$\sqrt{ } 8$ Contoh Teknik Analisis Data Kualitatif Karya Ilmiah/Makalah | PenelitianIlmiah.Com

Dampak privatisasi BUMN bagi perekonomian Indonesia? (marciadgembels.blogspot.com)

KEBIJAKAN PRIVATISASI BUMN : Relasi state, market and civil society | Ahabibullah's Blog (wordpress.com) 